\title{
A novel five-level switched capacitor type inverter topology for grid-tied photovoltaic application
}

\author{
Shakil Ahamed Khan \\ Electrical and Data Engineering \\ University of Technology Sydney \\ Sydney, Australia \\ Shakil. A. Khan@student.uts.edu.au
}

Yam Siwakoti

Electrical and Data Engineering

University of Technology Sydney

Sydney, Australia

Yam.Siwakoti@uts.edu.au

\author{
Md Noman Habib Khan \\ Electrical and Data Engineering \\ University of Technology Sydney \\ Sydney, Australia
}

MdNomanHabib.Khan@student.uts.edu.au

\author{
Jianguo Zhu \\ Electrical and Data Engineering \\ University of Technology Sydney \\ Sydney, Australia \\ Jianguo.Zhu@uts.edu.au
}

\author{
Youguang Guo \\ Electrical and Data Engineering \\ University of Technology Sydney \\ Sydney, Australia \\ Youguang.Guo-1@uts.edu.au
}

\begin{abstract}
This paper presents a novel five-level inverter topology and associated control scheme. The proposed structure consists of a capacitor, and eight active switching elements. It requires only one dc source and is capable of generating five voltage levels with double voltage boosting gain. On the other hand, it does not require any control scheme to balance the capacitor in the DC-bus due to inherent voltage balancing capability. As a result, the control complexity reduces a lot. Brief analysis followed by simulation and measurement results of a proposed 5-level inverter using the finite control set model predictive control (FCS-MPC) algorithm is presented. Detail of the analysis with more measurement result and comparison will be presented in the final paper.
\end{abstract}

Keywords- Photovoltaic system, FCS-MPC, Multilevel Inverter.

\section{INTRODUCTION}

Recently, multilevel inverters (MLIs) become popular in the industrial drives to use medium voltages to meet the high-power applications. Some of its advantages are: capable of synthesizing output voltages at more than two levels with the use of an array of semiconductor switches, low total harmonic distortion, low $\mathrm{dv} / \mathrm{dt}$ stresses, mitigating electromagnetic interference, smaller or even no output filter is required and the average switching frequencies of the MLIs are much lower than those of the conventional two level inverters [1]-[2]. Besides these numerous advantages, the cost and size are still the main issue due to the high number of required semiconductor devices and control complexity with the increasing levels of output voltage [3]. The basic topologies of the existing MLIs are the cascaded multilevel inverter topology, the diode-clamped multilevel inverter topology, and the flying-capacitor multilevel inverter topology [4]-[6]. Among these topologies, the Cascaded Multilevel Converter (CMC) has attracted more attention due to its simple structure and individual DC power sources for each cascaded unit. However, CMC does suffer from requiring several isolated dc sources [2], [7]. Therefore, many topologies have been proposed to focus on single source with less required semiconductor devices and overcome this pressing issue [8]-[9]. Topologies with common-ground terminal significantly reduce the number of power devices, whilst nullifying the leakage current to the grid [2], [10]. Similarly, multilevel converters, which clamp the common mode voltage (CMV) during the freewheeling period, have received more attention in the recent time for medium power PV applications as they adopt the concept of common ground for effective elimination of leakage current. However, the requirement of high dc-link voltage $(800 \mathrm{~V})$ in same of the conventional multilevel converters (neutralpoint-clamped (NPC), active NPC (ANPC) and T type [11][13] demand higher voltage boost converter at the front side. Inverter with integrated voltage boost capability has been alternatively seen as a potential candidate for PV applications due to its wide input voltage range.

This paper presents a switched capacitor type 5-level inverter, which uses a less number of semiconductor devices and has stepping-up feature suitable for PV applications. The paper is organized as follows. Section II shows the circuit configuration with operating principles. Section III explains the control strategy for the proposed topology. Section IV shows the comparison analysis of the proposed topology with existing topologies. Section $\mathrm{V}$ shows simulation waveforms in MATLAB-Simulink and the real time measurement results. The paper is summarized and concluded in Section VI. 


\section{CIRCUIT STRUCTURE AND OPERATING PRINCIPLE OF THE NOVEL FIVE-LEVEL INVERTER}

The proposed inverter topology consists eight switches where six switches (S_11,S_14, and S_1-S_4) are unidirectional and other two is bidirectional, and a capacitor as shown in Fig. 1. The capacitor is used to attain different voltage levels by charging and discharging in predefined switching states. During the inverter's operation, the capacitor charges in zero state and discharges in 2 nd level. The proposed inverter has five operating states as shown in Fig. 2. The status of the switches during each state and the corresponding output voltage is given in Table I. Each state will be described in the following subsections.

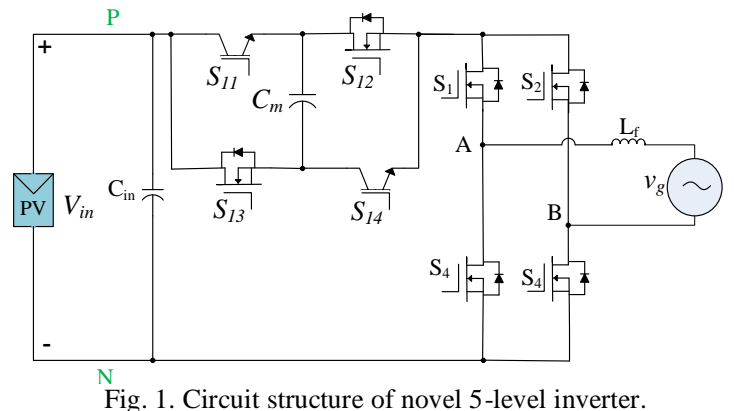

State $A$, and $B( \pm 1$ level $)$ :

In the State A (see Fig. 2 (a)), the output of the inverter before the filter is + VPN. The grid current goes to the switches $S_{11}, S_{12}, S_{1}$ and $S_{4}$. However, in Fig. 2 (b) shows the State B where other two switches $\left(S_{2}\right.$ and $\left.S_{3}\right)$ of the hbridge are $\mathrm{ON}$ and the output of the inverter before the filter is - VPN.

\section{State C,D (0 level):}

The zero level shows in State C and D (see Fig. 2 (c) and Fig. 2 (d)). The switches $S_{1}$ and $S_{3}$ are closed to form a bidirectional path for current flow during both the positive and negative cycle zero states. This leads to a zero voltage being applied before the output filter. The switches $S_{11}, S_{14}$ $S_{1}$ and anti-parallel diode of switch $S_{2}$ are ON during the positive half cycle while switches $S_{11}, S_{14}, S_{3}$ and antiparallel diode of switch $S_{4}$ are $\mathrm{ON}$ for negative half cycle.

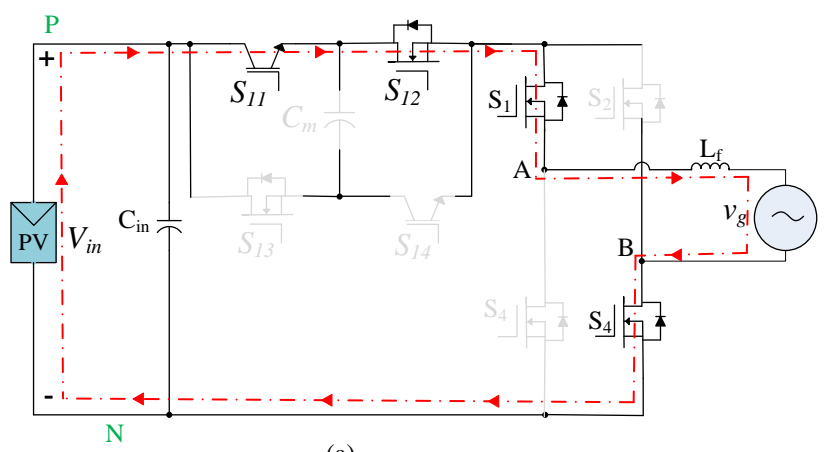

(a)

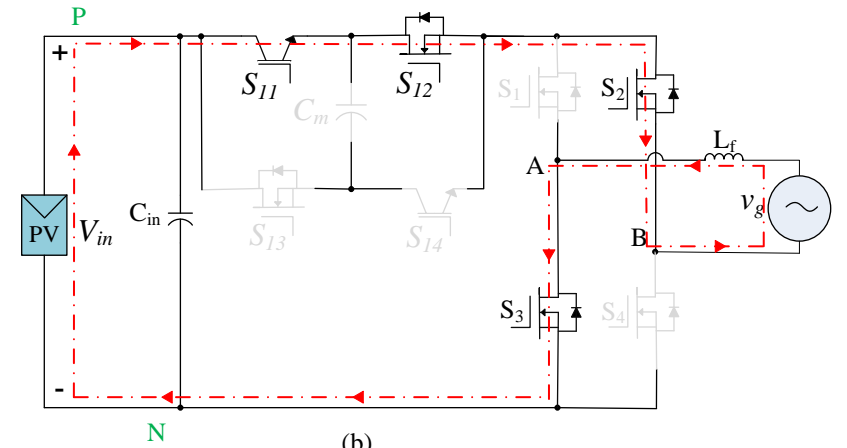

(b)

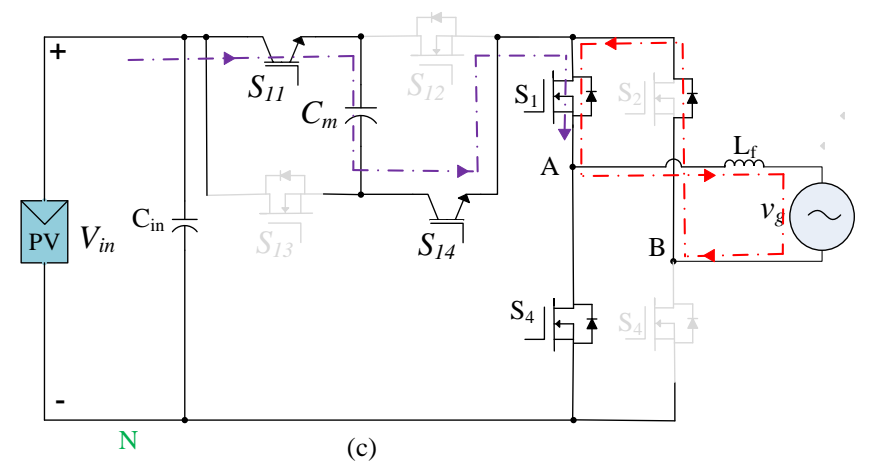

(c) 

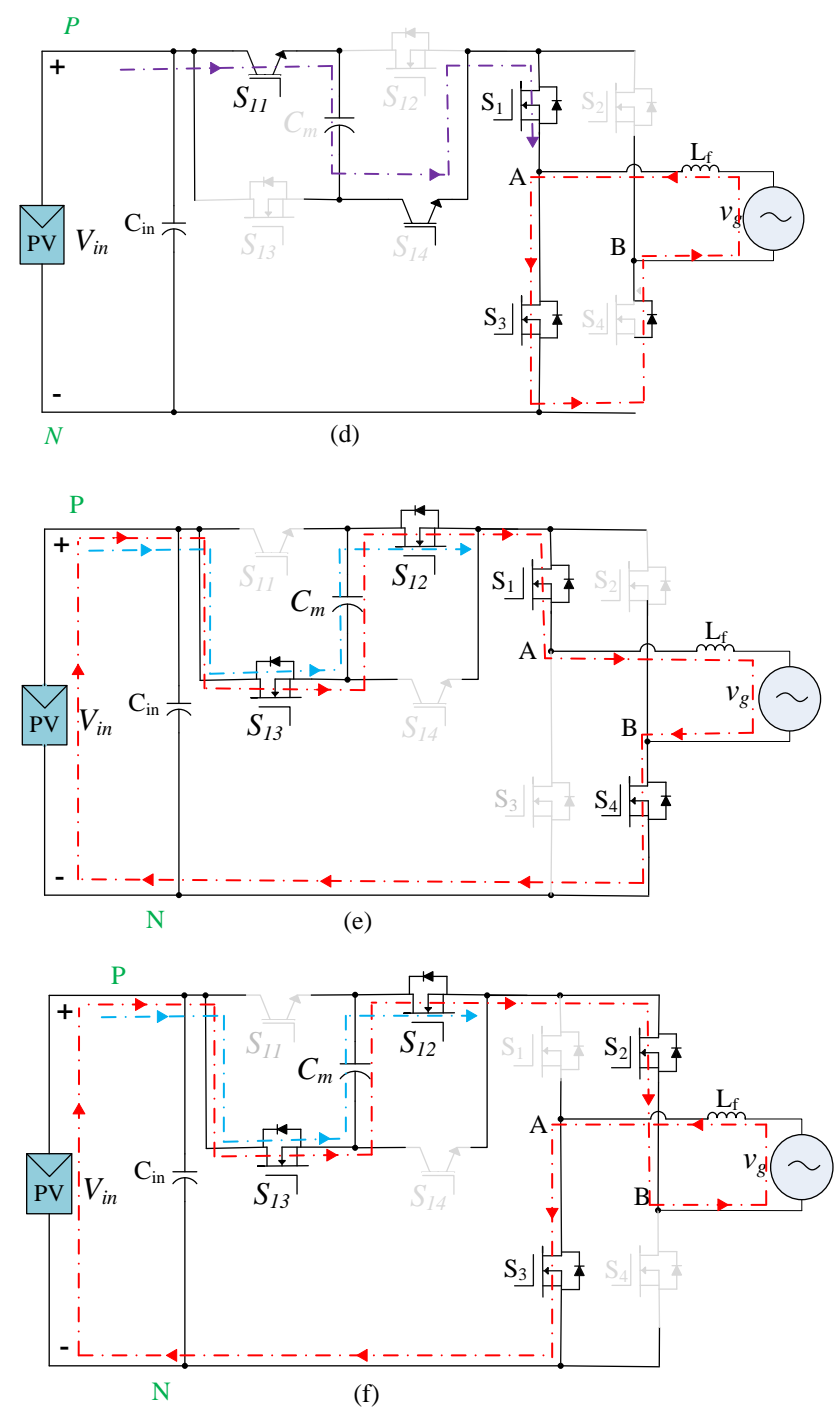

Fig. 2. Operation modes of proposed 5-level inverter: (a) Mode A $\left(+1 \times V_{i n}\right) x$ (b) Mode B $\left(-1 \times V_{i n}\right) x$ (c) Mode C $\left(+0 \times V_{i n}\right),(d)$ Mode D ($\left.0 \times V_{i n}\right)$, (e) Mode $\mathrm{E}\left(+2 \times V_{i n}\right)$, and (f) Mode F $\left(-2 \times V_{i n}\right)$.

\section{State $E, F( \pm 2$ level $)$ :}

Fig. 2(d) and Fig. 2(e) shows State E, and State F respectively. The capacitor $C_{\mathrm{m}}$ is discharged in series through the switches $S_{12}, S_{13}, S_{1}$ and $S_{4}$ for positive half cycle and output current flows through the same way to create positive two level $\left(+2 V_{\mathrm{PN}}\right)$. On the other hand, the capacitor $C_{m}$ is discharged in series through the switches $S_{13}, S_{12}, S_{1}$ and $S_{4}$ for negative half cycle and output current flows through the same way to create negative two level $\left(-2 V_{\mathrm{PN}}\right)$.

TABLE I

SWITCHING STATES OF THE PROPOSED TOPOLOGY

\begin{tabular}{|c|c|c|c|c|c|c|c|c|c|c|}
\hline \multirow{2}{*}{ Mode } & \multicolumn{7}{|c|}{ Switches } & \multirow{2}{*}{$*$} & $\begin{array}{c}\text { Output } \\
\text { Voltage } \\
\text { Level }\end{array}$ \\
\cline { 2 - 10 } & $S_{I I}$ & $S_{12}$ & $S_{12}$ & $S_{14}$ & $S_{I}$ & $S_{I 2}$ & $S_{I}$ & $S_{4}$ & & +1 \\
\hline A & 1 & 1 & 0 & 0 & 1 & 0 & 0 & 1 & $1 / 2$ & -1 \\
\hline B & 1 & 1 & 0 & 0 & 0 & 1 & 1 & 0 & $-1 / 2$ & +0 \\
\hline C & 1 & 0 & 0 & 1 & 1 & 0 & 0 & 0 & 0 & +0 \\
\hline D & 1 & 0 & 0 & 1 & 0 & 1 & 0 & 0 & 0 & -0 \\
\hline E & 0 & 1 & 1 & 1 & 1 & 0 & 0 & 1 & 1 & +2 \\
\hline F & 0 & 1 & 1 & 1 & 0 & 1 & 1 & 0 & -1 & -2 \\
\hline
\end{tabular}

\section{CONTROL STRATEGY FOR PROPOSED TOPOLOGY}

A finite control set model predictive control (FCS-MPC) algorithm is derived to drive the proposed multilevel converter. In the proposed control scheme, the predictive current control scheme is used. The proposed multilevel inverter can be modelled in the stationary reference frame as follows:

$$
\begin{aligned}
& \frac{d i_{g}(t)}{d t}=\frac{1}{L_{f}}\left(v_{A B}(t)-v_{g}(t)-i_{L f}(t) R_{S R}\right) \\
& v_{A B}(t)=\psi(t) v_{d c}(t)
\end{aligned}
$$

where $i_{g}(t)$ is the grid current, $i_{p c}$ represents the current at the point of common coupling, $R_{S R}$ is the equivalent series resistance value of the $L_{f}, V_{A B}(t)$ is the input of the multilevel inverter, $V_{g}(\mathrm{t})$ is the voltage at the point of common coupling, and $\psi(t)$ represents the control input obtained from the Table I.

By applying Euler forward method), the predictive values of the grid current can be expressed as follows:

$$
i_{g}{ }^{k+1}=i_{K}{ }^{k}+\frac{T_{s}}{L_{f}}\left(v_{A B}{ }^{k}-v_{g}{ }^{k}-i_{L f}{ }^{k} R_{S R}\right)
$$

Fig. 3 shows the block diagram of the diagram of the FSC-MPC control strategy with proposed topology where realize the desired active and reactive power with the proposed MLI during the grid-connected mode, the predictive grid current is calculated in terms of reference active and reactive power values.

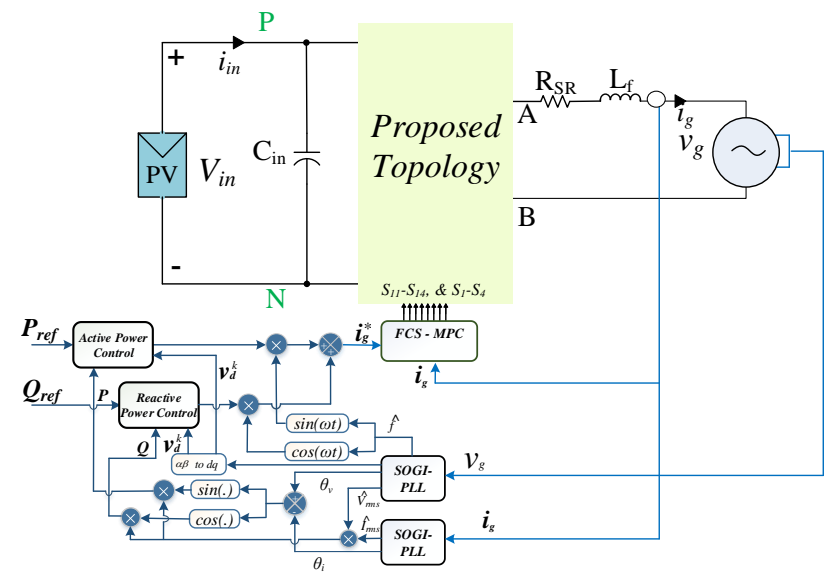

Fig. 3. The block diagram of the total control strategy with proposed topology.

The instantaneous active power value $p^{k}$ and the instantaneous reactive power value $q^{k}$ in a single-phase power system can be presented as follows:

$$
\left[\begin{array}{c}
p^{k} \\
q^{k}
\end{array}\right]=\frac{1}{2}\left[\begin{array}{cc}
v_{s d}{ }^{k} & v_{s q}{ }^{k} \\
v_{s q}{ }^{k} & -v_{s d}{ }^{k}
\end{array}\right]\left[\begin{array}{c}
i_{s d}{ }^{k} \\
i_{s q}{ }^{k}
\end{array}\right]
$$

where $v_{s d}, v_{s q}$ are the $d$-axis and $q$-axis components of the power grid voltage $v_{s}$, and $i_{s d}$ and $i_{s q}$ are the $d$-axis and $q$ axis components of the grid current $\left(i_{s}\right)$ in the $d q$ rotating frame.

The utility voltage $\left(v_{s}\right)$ is in phase with the $d$-axis component in synchronous reference frame. Therefore, $p^{k}$ and $q^{k}$ can be expressed as: 


$$
p^{k}=\frac{1}{2} v_{s d}{ }^{k} i_{s d}{ }^{k}
$$

$$
q^{k}=-\frac{1}{2} v_{s d}{ }^{k} i_{s q}{ }^{k}
$$

Finally, by using (5) and (6), the current references can be expressed as:

$$
i_{g}{ }^{k}=\frac{2 p^{k}}{v_{s d}{ }^{k}} \sin (\theta)-\frac{2 q^{k}}{v_{s d}{ }^{k}} \cos (\theta)
$$

The control objective of the proposed system is to inject the desired active and reactive powers into the grid. Based on the reference power values, the reference grid current is calculated from (7), where the value of the grid voltage angle is calculated from the phase-locked loop (PLL) algorithm.. In the proposed control scheme, the cost function formulation for the converter is given in the follow:.

$$
g_{\text {MLI. }}=\left(i_{g}{ }^{k+1}-i_{g}{ }^{k+1}\right)^{2}
$$

In contrast to the existing topologies, the proposed topology inherently overcomes the voltage unbalancing problems. Thus, it does not require any control scheme to generate balanced voltages in the DC link capacitors.

This cost function is valid for any number of voltage level generation with the proposed architecture. The proposed cost function does not include any weighting factor. Thus weighting factor tuning is not necessary for different operating conditions.Before you begin to format your paper, first write and save the content as a separate text file. Complete all content and organizational editing before formatting. Please note sections A-D below for more information on proofreading, spelling and grammar.

Keep your text and graphic files separate until after the text has been formatted and styled. Do not use hard tabs, and limit use of hard returns to only one return at the end of a paragraph. Do not add any kind of pagination anywhere in the paper. Do not number text heads-the template will do that for you.

\section{COMPARISON ANALYSIS WITH CONVENTIONAL FIVE- LEVEL TOPOLOGIES}

Multilevel inverter is widely researched in both academia and industrial research institutes. However, the most challenging part is to reduce the number of semiconductor devices in the inverter topology to improve efficiency and power density. Table II illustrates the comparison of different single-phase multilevel inverter topologies in terms of the input voltage, Output voltage, power semiconductor devices, additional devices, boosting feature, required isolated DC source, and reactive power capability. The NPC inverter is constructed by eight power switches and four diodes to achieve five levels, while ANPC and T-type five-level inverter have no requirements of diodes. Instead, they require additional capacitors. Moreover, they require 2 V_PN input supply voltage to produce the 230 Vac RMS. DCC, FCC, and CMC use eight power switches; however, the DCC requires extra four capacitors and 12 diodes to achieve five levels in the output voltage. Moreover, CMC needs isolated DC sources. In summary, it is to be noted that the proposed topology needs only around $200 \mathrm{~V}$ dc-input voltage to obtain $230 \mathrm{~V}$ ac RMS. In addition, the required components for a 5level inverter are one capacitor and eight power switches.

\begin{tabular}{|c|c|c|c|c|c|c|c|c|}
\hline \multirow{2}{*}{ Topologies } & \multirow{2}{*}{$\begin{array}{c}\text { Input } \\
\text { voltage, } \\
\left(V_{\text {In }}\right)\end{array}$} & \multirow{2}{*}{$\begin{array}{c}\text { Output } \\
\text { voltage, } \\
\left(V_{\text {owt }}\right)\end{array}$} & \multicolumn{2}{|c|}{$\begin{array}{c}\text { Power } \\
\text { devices }\end{array}$} & \multicolumn{2}{|c|}{$\begin{array}{c}\text { Additional } \\
\text { devices }\end{array}$} & \multirow{2}{*}{\begin{tabular}{|c} 
Step \\
Up \\
feature
\end{tabular}} & \multirow{2}{*}{$\begin{array}{c}\text { Need } \\
\text { isolated DC } \\
\text { sources }\end{array}$} \\
\hline & & & D & $S$ & L & C & & \\
\hline $\begin{array}{l}\text { Topology } \\
\text { in [14] }\end{array}$ & $V_{P N}$ & $\begin{array}{c}230 / 50 \\
\mathrm{~Hz}\end{array}$ & 0 & 10 & 0 & 3 & No & no \\
\hline $\begin{array}{l}\text { Topology } \\
\text { in [15] }\end{array}$ & $V_{P N}$ & $\begin{array}{c}230 / 50 \\
\mathrm{~Hz}\end{array}$ & 0 & 10 & 0 & 3 & Yes & no \\
\hline $\begin{array}{l}\text { Topology } \\
\text { in [16] }\end{array}$ & $V_{P N}$ & $\begin{array}{c}230 / 50 \\
\mathrm{~Hz}\end{array}$ & 0 & 13 & 0 & 4 & No & no \\
\hline $\begin{array}{l}\text { Topology } \\
\text { in [17] }\end{array}$ & $\frac{V_{P N}}{2}$ & $\begin{array}{c}220 / 50 \mathrm{H} \\
\mathrm{z}\end{array}$ & 10 & 8 & 4 & 4 & Yes & yes \\
\hline $\begin{array}{l}\text { Topology } \\
\text { in [18] }\end{array}$ & $V_{P N}$ & $\begin{array}{c}110 / 50 \\
\mathrm{~Hz}\end{array}$ & 2 & 8 & 2 & 4 & Yes & yes \\
\hline $\begin{array}{l}\text { Topology } \\
\text { in [19] }\end{array}$ & $V_{P N}$ & $\begin{array}{c}110 / 50 \\
\mathrm{~Hz}\end{array}$ & 4 & 4 & 0 & 2 & No & yes \\
\hline $\begin{array}{l}\text { Topology } \\
\text { in [20] }\end{array}$ & $V_{P N}$ & $\begin{array}{c}115 / 50 \\
\mathrm{~Hz}\end{array}$ & 2 & 6 & 0 & 2 & No & no \\
\hline $\begin{array}{l}\text { Topology } \\
\text { in [21] }\end{array}$ & $\frac{V_{P N}}{2}$ & $\begin{array}{c}120 / 60 \\
\mathrm{~Hz}\end{array}$ & 3 & 8 & 2 & 4 & Yes & yes \\
\hline $\begin{array}{l}\text { Proposed } \\
\text { Inverter }\end{array}$ & $\frac{V_{P N}}{2}$ & $\begin{array}{c}230 / 50 \\
\mathrm{~Hz}\end{array}$ & 0 & 8 & 0 & 1 & Yes & no \\
\hline
\end{tabular}

TABLE II.

COMPARISON TABLE OF EXISTING 1-Ø 5-L INVERTER TOPOLOGIES WITH PROPOSED TOPOLOGY

Note: $\mathrm{D}=$ diode, $\mathrm{S}=\mathrm{S}$ witch, $\mathrm{L}=$ inductor, $\mathrm{C}=$ capacitor

\section{Simulation And Measurement Results}

The proposed inverter is validated using a MATLAB simulation. Table III displays the list of components and parameters used for both simulations and measurements. TABLE III.

PARAMETERS USED FOR SIMULATION AND EXPERIMENT.

\begin{tabular}{|c|c|}
\hline Parameter & Value \\
\hline Input Voltage $\left(\mathrm{V}_{\text {in }}\right)$ & $200 \mathrm{~V}-\mathrm{DC}$ \\
\hline Resistive Load & $52 \Omega$ \\
\hline Output Voltage $\left(\mathrm{V}_{\text {grid }}\right)$ & $230 \mathrm{~V} \mathrm{AC}$ \\
\hline Line Frequency $\left(f_{g}\right)$ & $50 \mathrm{~Hz}$ \\
\hline Output Current $\left(i_{0}\right)$ & $4.7 \mathrm{~A}$ \\
\hline Modulation Index $(\mathrm{M})$ & 0.92 \\
\hline Rated Power & $1 \mathrm{~kW}$ \\
\hline Switching Frequency $\left(\mathrm{f}_{\text {gw }}\right)$ & $20 \mathrm{kHz}$ \\
\hline DC Bus Capacitor $\left(\mathrm{C}_{\mathrm{dcl}}=\mathrm{C}_{\mathrm{dc}}\right)$ & $680 \mu \mathrm{F}$ \\
\hline Filter Capacitor $\left(\mathrm{C}_{0}\right)$ & $2.2 \mu \mathrm{F}$ \\
\hline Filter Inductor $\left(\mathrm{L}_{1}, \mathrm{~L}_{2}\right)$ & $2 \mathrm{mH}$ \\
\hline
\end{tabular}

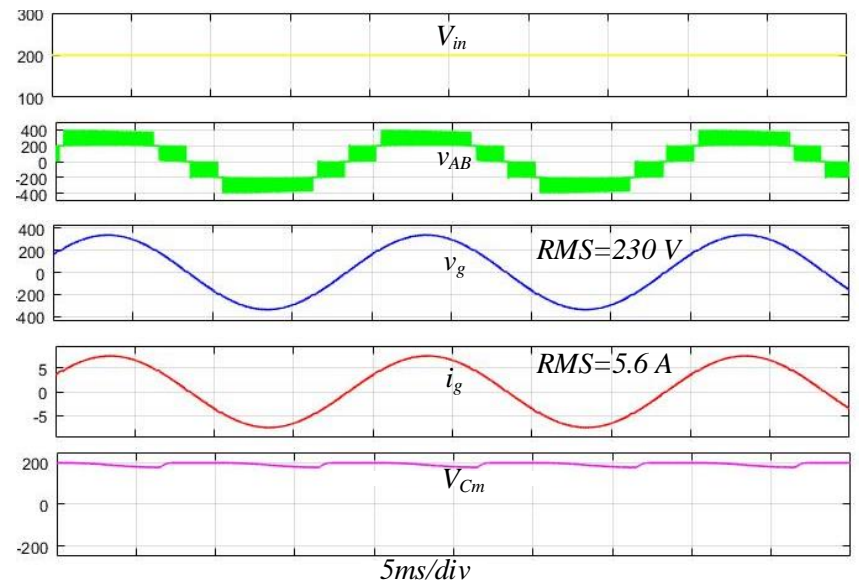

(a) 

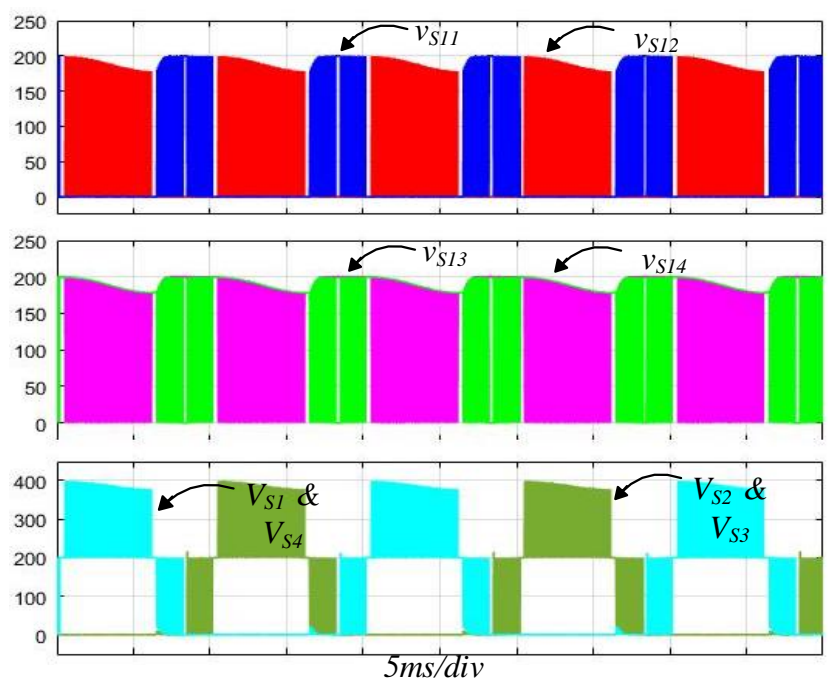

(b)

Fig.3. Simulated waveform of the proposed topology: (a) input and output waveforms, (b) voltage stress.

Agilent Technologies

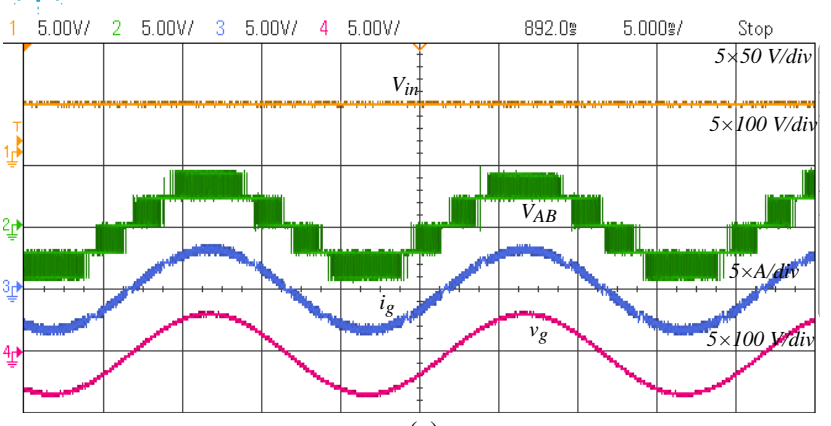

(a)

\section{Agilent Technologies}

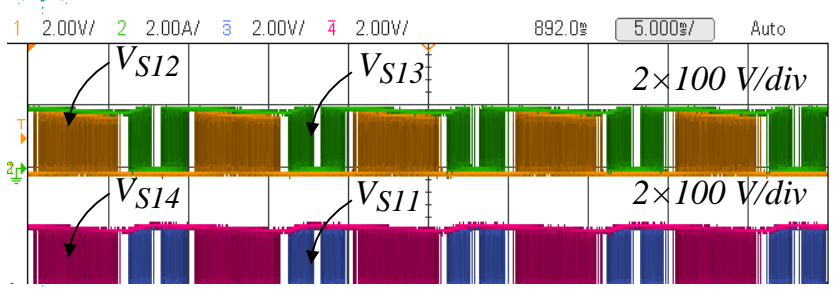

Agilent Technologies

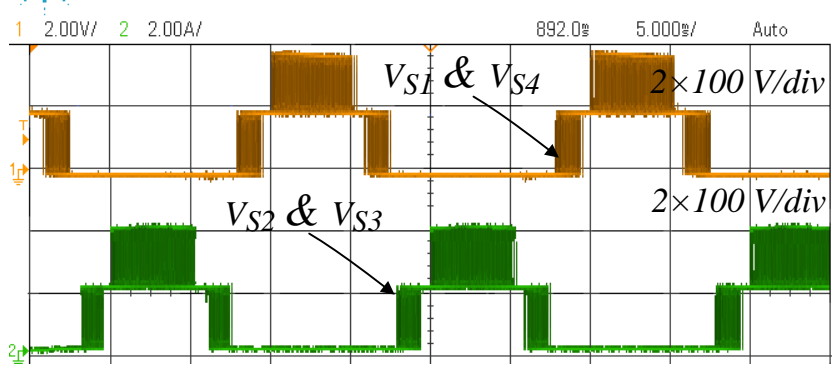

(b)

Fig. 4. Measurement results of the proposed topology: (a) input and output waveforms, (b) voltage stress

Fig. 3, and Fig. 4, show the waveforms of the proposed inverter with input voltage $200 \mathrm{~V}$ to obtain $230 \mathrm{Vac}$ RMS as shown in Fig. 3(a). The 5L voltage is filter out by an L-type filter to get a pure sinusoidal voltage and current at the grid.

\section{CONCLUSION}

A novel 5-level step up inverter for single-phase photovoltaic (PV) applications has presented with details control scheme. This topology does not require any control scheme to balance the series connected capacitor in the DCbus due to inherent voltage balancing capability. Thus, it reduces the control complexity. Detailed analysis followed by simulation and real time measurement results of a proposed 5-level inverter by using the finite control set model predictive control (FCS-MPC) algorithm is presented.

\section{References}

[1] H. K. Jahan, M. Abapour, \& K. Zare, "Switched-capacitor-based single-source cascaded H-bridge multilevel inverter featuring boosting ability," in Proc. IEEE Trans. Power Electron., vol. 34, no.2, pp.1113-1124, Feb. 2019.

[2] M. N. H. Khan, Y. Siwakoti, L. Li, and M. Forouzesh, "Single-Phase Switched-Capacitor Integrated-Boost Five-level Inverter," in Proc. IEEE Region 10 Symp. (TENSYMP), Sydney,4-6 Jul. 2018, pp. 2529.

[3] S. A. Amamra, K. Meghriche, A. Cherifi, \& B. Francois, "Multilevel inverter topology for renewable energy grid integration,". IEEE Trans. Ind. Electron., vol.64, no.11, pp. 8855-8866. Nov. 2017.

[4] K. Corzine and Y. Familiant, "A new cascaded multilevel H-bridge drive," IEEE Trans. Power Electron., vol. 17, no. 1, pp. 125-131, Jan. 2002.

[5] J. S. Lai and F. Z. Peng, "Multilevel converters-a new breed of power converters," IEEE Trans. Ind. Appl., vol. 32, no. 3, pp. 509-517, Jun. 1996.

[6] R. H. Baker and L. H. Bannister, "Electric Power Converter," ed: Google Patents, 1975.

[7] H. K. Jahan, M. Abapour, \& K. Zare, "Switched-capacitor-based single-source cascaded H-bridge multilevel inverter featuring boosting ability," IEEE Trans. Power Electron., vol. 34, no. 2, pp. 1113-1124, Apr. 2018.

[8] Y. P. Siwakoti, "A new six-switch five-level boost-active neutral point clamped (5L-Boost-ANPC) inverter," in Proc. IEEE Appl. Power Electron. Conf. Expo. (APEC), San Antonio, TX, 4-8 Mar. 2018, pp. 2424-2430.

[9] B. Shaffer, H. A. Hassan, M. J. Scott, S. U. Hasan, G. E. Town, and Y. Siwakoti, "A common-ground single-phase five-level transformerless boost inverter for photovoltaic applications," in Proc. IEEE Appl. Power Electron. Conf. Expo. (APEC), San Antonio, TX, 4-8 Mar. 2018, pp. 368-374.

[10] M. N. H. Khan, M. Forouzesh, Y. Siwakoti, and L. Li, "Novel High Efficiency H-Bridge Transformerless Inverter for Grid-Connected Single-Phase Photovoltaic Systems," in Proc. IEEE Region 10 Symposium (TENSYMP), Sydney,4-6 Jul. 2018, pp. 95-99.

[11] A. Nabae, I. Takahashi, and H. Akagi, "A new neutral-point-clamped PWM inverter," IEEE Trans.Ind. Appl., vol. IA-17, no. 5, pp. 518523, Sept. 1981.

[12] T. Bruckner, S. Bernet, and H. Guldner, "The Active NPC Converter and Its Loss-Balancing Control," IEEE Trans. Ind. Electron., vol. 52, no. 3, pp. 855-868, Jun. 2005.

[13] D. Leuenberger, and J. Biela, "Comparison of a soft switched TCM T-Type inverter to hard switched inverters for a 3 phase PV grid interface," in Proc. IEEE 15th Int. Power Electron. Motion Control Conf. (EPE/PEMC), 2012 (pp. LS1d.1- LS1d.8).

[14] H. Vahedi, P.-A. Labbé, and K. Al-Haddad, "Sensor-less five-level packed U-cell (PUC5) inverter operating in stand-alone and gridconnected modes," IEEE Trans. Ind. Inf., vol. 12, no. 1, pp. 361-370, Feb. 2016.

[15] B. Chen, W. Yao, and Z. Lu, "Novel five-level three-phase hybridclamped converter with reduced components," J. Power Electron., vol. 14, no. 6, pp. 1119-1129, Nov. 2014.

[16] M. Norambuena, S. Kouro, S. Dieckerhoff, and J. Rodriguez, "Reduced Multilevel Converter: A Novel Multilevel Converter With a Reduced Number of Active Switches," IEEE Trans. Ind. Electron., vol. 65, no. 5, pp. 3636-3645, May. 2018. 
[17] T. T. Tran, and M. K. Nguyen "Cascaded five-level quasi-switchedboost inverter for single-phase grid-connected system," IET Power Electron., vol. 10, no. 14, pp. 1896-1903, Nov. 2017.

[18] M. K. Nguyen, \& T. T. Tran, "Quasi cascaded H-bridge five-level boost inverter," IEEE Trans. Ind. Electron.," vol. 64, no. 11, pp. 8525-8533, Nov. 2017.

[19] Y Hu, Y Xie, L Cheng, and D Fu., "Characteristics analysis of a new single-phase $\pi$-type five-level inverter," IET Power Electron., vol. 9, no. 6, pp. 1290-1296. May. 2016.
[20] V Monteiro, JC Ferreira, AAN Meléndez, and J. L. Afonso, "Model predictive control applied to an improved five-level bidirectional converter," IEEE Trans. Ind. Electron., vol. 63, no. 9, pp. 5879-5890, Sept. 2016.

[21] A. V. Ho, \& T. W. Chun, "Single-Phase Modified Quasi-Z-Source Cascaded Hybrid Five-Level Inverter," IEEE Trans. Ind. Electron., vol. 65 , no. 6 , pp. 5125-5134, Jun. 2018 